\section{ASSOCIATION OF SPECIAL LIBRARIES AND INFORMATION BUREAUX}

\section{ANNUAL CONFERENCE}

$\mathrm{T}$ HE nineteenth annual conference of the Association of Special Libraries and Information Bureaux, held in the rooms of the Royal Society on December 9 and 10, 1944, was one of the best attended conferences of the Association, and most of the sessions were characterized by animated disoussions which indicated a live interest on the part of the general body of members.

In his opening presidential address, on "Organized Knowledge in the World of the Future", Sir Frederic Kenyon, after congratulating the Association on its achievements, said that the raison d'être of ASLIB is the service of humanity by the organized supply of knowledge. While the service of industry is its first and most obvious activity, he believes that knowledge must not be restricted to such utilitarian spplication but applied in the most liberal spirit to the whole of our national life. We cannot rest satisfied with the lack of appreciation of the knowledge, the skill and the inventiveness to be found in British science and scholarship and with the failure to apply them. The practical value of scientific research can no longer be denied and Sir Frederic hopes that we shall not grudge expenditure on free disinterested studies. While, however, it is right that we should try to make this knowledge readily available for those who are able to use it, that alone is not enough. Knowledge can be curse as well as blessing, and Sir Frederic urged that knowledge must be not merely organized but also its use controlled by principles of higher validity than material power. Knowledge is good, but its value is related to something higher still which Plato called the idea of good, and which Bacon called God. Sir Frederic believes that the welfare of the nation and of the world at large depends on a change of soul and a change of living, which can only be effected by a change of principle from competition to co-operation, from organization to morality or religion. The organization of knowledge must be harnessed to moral standards if strength and wisdom are to be brought together.

The first session of the Conference was devoted to a particular aspect of this co-operation, "The Empire Contribution to the Flow of World Information", and Prof. R. S. Hutton presided. As a basis for discussion, members of the Conference had before them nine papers describing various specialized sources of information on and within the British Empire; those of Mr. R. L. Sheppard, Mr. Kenneth Binns, Mr. G. B. Gresford and Mr. A. L. Poole were presented in person. Some notes on the India House Library were also available at the Conference. Sir Harry Lindsay described the work of the Imperial Institute as a special library and information bureau. Sir David Chadwick outlined the work of the twelve Imperial Agricultural Bureaux. Mr. Sheppard described the development and work of the Bureau of Hygiene and Tropical Diseases from the Sleeping Sickness Bureau which eommenced work on June 1, 1908, in a room at the Royal Society. The Bureau is now responsible for the issue of the Tropical Diseases Bulletin, the Bulletin of Hygiene and the Bulletin of War Medicine, and surveys for this purpose some 650 English and foreign medical and scientific perıodicals. The abstracting is done by a panel of more than two hundred contributors specially associated with the subjects they review, and Mr. Sheppard emphasized the critical character of the abstracts issued.

A note on the Library of the Royal Empire Society in 1944 was contributed by Mr. Evans Lewin, who described its work more fully at the 1933 Conference. The note included a select list of periodical publications received in the Library; and a list of sources of Canadian bibliographical information was for. warded by Mr. C. R. Sanderson, chief librarian of the Public Library of Toronto, among which the Canadian catalogue of books published in Canada, about Canada, as well as those written by Canadians, was singled out for mention by Prof. Hutton. This has been published annually since 1923 by the Toronto Public Libraries.

The flow of information between Britain and Australia was discussed by Mr. Binns, who stated that a second edition of "Pitt's Catalogue of the Scientific and Technical Periodicals in the Libraries of Australia" is in preparation, and that a similar work on the social sciences is planned by the National Library. The National Library has also issued annually, since 1936, a fairly complete list of publications appearing in the Commonwealth or touching Australia ; and this, and a Select List of Representative Works dealing with Australia, issued annually since 1934, has been freely available to overseas libraries and institutions on an exchange basis. The Australian National Research Council also publishes Australian Science Abstracts ; but in reply to a question, Mr. Binns admitted that this has a very limited circulation. He also referred to the establishment this year at Australia House, London, of an Australian Library of Information as an activity of the National Library at Canberra. A further paper, "Notes on Library and Information Services in Australia", presented by Mr. G. B. Gresford, emphasized the value of "Pitt's Catalogue of Scientific and Technical Periodicals in Australian Libraries", and also referred to the Scientific Liaison Bureau set up in 1942 by the Commonwealth Government and to the Information Section maintained by the Council for Scientific and Industrial Research. In concluding, he referred to the two schools of thought in Australia with regard to the publication of sciontific research, and invited opinion as to the desirability or otherwise of publication in Australian periodicals or overseas. In response to this invitation, it was urged during the discussion that a policy of publication in the established British and American periodicals, such as the Journal of the Chemical Society and the Journal of the American Chemical Society, should be followed, and efforts made to avoid the multiplication of periodicals the circulation of which could only be limited.

In a further paper, Mr. A. L. Poole contributed some notes on the organization of scientific research in New Zealand with a list of sources of bibliographical information on New Zealand, while the final paper in the symposium, communicated by Mr. P. Freer, on "Bibliographical Work in South Africa", in addition to enumerating the chief guides to recent literature of the Union, made a number of suggestions for improvement of co-operation, some of which were taken up in the ensuing discussion. Among these suggestions were the improvement of book supply centres in South Africa, possibly inter-allied book centres in co-operation with the British Council, 
co-operative cataloguing, reprinting of important books now out of print and the exchange of staff between the National Central Library and the Dominion State libraries. Very little tangible result emerged from the discussion, though there was elearly support in general for further co-operation in various directions, including abstracting, between English-speaking countries. No evidenee was supplied that much progress has been made as yet on the lines indieated in the report of the British Commonwealth Science Committee, but some reference was made to Dr. Needham's more recent proposals (see Nature, November 25, pp. 649, 657).

The second session of the Conference was devoted to a paper on "Trade Catalogues in the Commercial Library", by Mr. G. K. Wilkie, who briefly described the collection of such catalogues in the Leicester Municipal Libraries, indicating its value as a source of technical information, the way in which the collection was formed and the method of making it available to the public. $\mathrm{H}_{\theta}$ favours the vertical file system of housing, and stressed the importance of having the right person in charge of any such collection.

Past conferences of the Association have frequently suffered from the attempt to cram two papers into a session barely adequate for the discussion of one, and of this the third session was an unhappy example. Mr. E. Carter's able chairmanship could not avoid an untimely termination of the discussions stimulated by Mr. G. A. Shires' paper, 'The Technical Information Bulletin and what to put in it", and Mrs. Moholy's report on microfilm developments. $\mathbf{M r}$. Shires outlined the general policy on which the service offered was based, as shown in the issue of such a bulletin in the Dunlop Rubber Company. He aroused lively curiosity as to the means by which he secured the efficient production of abstracts from specialist members of the technical staff; but only the barest discussion of the material aspect or of the principles followed in the selection and presentation of material was possible. Mrs. Lucia Moholy presented her report on "Developments and Extensions in the Uses of Microfilm". This paper covered the period since her report to the Association's Conference in November 1942. The day-to-day activities of the ASLIB mierofilm service include the recording in detail of every strip of film of which a master negative is retained, catalogue entries with all available particulars which serve as a basis for the aequisition of new items, and the development of special filing arrangements. Co-operation with Government departments and special libraries has enabled the service to be extended far beyond the originel scope of a technical unit. Dr. Moholy visualizes two main tasks for documentary reproduction in the projects of an internationel clearing house of library services and for scientific co-operation : the interchange of complete books, periodicals and other publications on microfilm, and the supply of articles from periodicals, excerpts from books and other selected items for specialized research on film strips, in microprint or photostat copies as required. Documentary reproduction would be of special importance in cooperation with an international research service as a technical section covering all branches of learning - the scienoes and the humanities.

An adequate supply of reading machines is still laoking, and Dr. Moholy does not think that the failure to meet the demand can be justified merely by wartime difficulties. First-class microfilm readers are still manufactured in the United States; but the supply is restricted to those who can obtain the necessary permits and high priority. Recently, a microfilm viewer has been designed in the United States for a special purpose. This reader, which was exhibited at the Conferenee, folds into a flat box 5 in. by 2 in. and weighs less than $2 \mathrm{oz}$. It is useful for looking up references and may in emergency serve for reading a few pages, but is not suited for research purposes. Reference was also made to the recommendations on filing and storing microfilm issued this year by the British Standards Institution (B.S. 1153-1944), and to the possibilities of mieroprint as recently emphasized by Fremont Rider in his book "The Scholar and the Future of the Research Library" (see Nature, November 25, p. 655). Mrs. Moholy pointed out that microprint is only justifiable for a considerable number of copies and is thus on an equal footing with printed matter and subject to copyright. If the technique of microprinting is adopted in Great Britain, a similar or supplementary agreement like the draft agreement on microfilm issued by the Publishers' Association in co-operation with the Society of Authors, and in eonsultation with the Association of Special Libraries and Information Bureaux, and published in the Bookseller of July 7, 1944, would be required. Mrs. Moholy's report, and the subsequent discussion, indicated a more sober view of miorofilm and of its limitations than formerly prevailed, and that it must be regarded as supplementary, not replacing, other means, such as photostats.

The next session of the Conference, over.which $\mathrm{Mr}$. C. le Maistre presided, considered a paper by Mr. E. R. MeColvin on "The Education and Status of Special Librarians", which was based on the answers to a questionnaire circulated to members of the Association, chielly on the replies received from research organizations, industrial or commercial organizations and Government departments. Mr. McColvin emphasized that organization would be better and more efficient the fewer the dead end positions at any level to be found in it. His analysis of the requirements of both junior and senior staff led him to outline syllabuses suggested by the ASLIB Education Committee. This paper was followed by one by Miss Ruth S. Leonard on the recruitment and training of special librarians to fit the present and future needs of the speoial library profession in the United States. Throughout the animated discussion on these two papers, there was a pronounced cleavage of opinion, as was also evident in the voting on a resolution in favour of the question being taken up by the Association. It is diffieult to see that any substantial advance has been made since the question was last debated at the Assoeiation's Conference of 1935.

At the final session, when Sir Hugh Beaver presided, Mr. A. B. Agard Evans presented a paper on "Some Aspects of a new Technical Information Service in War-time", in which he discussed such problems against the background of the experience of the Records Section of the Research and Experiments Department of the Ministry of Home Security. This Records Section was part of the initial organization of the Department which came into being in February 1939 under the chief adviser, Dr. R. E. Stradling, then director of building research under the Department of Scientific and Industrial Research. Collaboration of the records officers of the three Service departments, other Government departments and of technical institutions was secured, and the 
A.R.P. Department and the Building Research Station in particular provided a valuable nucleus of tochnical information, and the Civil Defence Research Committee established in May 1939 was a further focus. Mr. Evans also referred to the generous help of the Patent Office Library, the Science Museum Library, the British Library of Political and Economic Science and the Royal Institute of British Architects. To the main subjects originally covered, such as H.E. and incendiary bombs, blast, ballistics, fragmentation and penetration, building and strength of materials, were soon added others such as lighting and black-out, physiological and psychological effects, camouflage and paint, window protection, location of industry and population. In regard to shelving, Mr. Evans stated that, as in other stations of the Department of Scientific and Industrial Research, books are shelved under broad subject headings, pemphlets by country and institution, periodicals alphabetically by title. In regard to book buying, he suggested that it would be of great value to librarians if publishers would set up a joint central library of new technical books where they could be inspected with the view of purchasing through the usual channels. Mr. Evans also commented on the limitations of microfilm, and appeared to lean rather to a photostat, urging strongly the termination of the system of loaning heavy bound periodicals and substituting a photostat or microfilm copy of the article required.

\section{STUDIES OF THE AMARYLLIDACEA}

$\boldsymbol{H}$ $E R B E R T I A$, the year-book of the American Amaryllis Society, has now reached its tenth volume (from L. S. Hannibal, Concord, California, July 1944). This publication maintains its potent blend of science with practice. It employs fertility in number of its titles with economical expression in its individual papers, to achieve a wide review of all questions which affect the horticulture of Amaryllids. Many facets are discussed-personal, historical, and cultural. In the sections on classification, genetics, the physiology of reproduction, and pathology, several interesting facts appear.

Dr. Hamilton P. Traub, editor of Herbertia, has published an account of the tribe Brunsvigieæ, which, it is proposed, should now include the genera Crinum, Brunsvigia, Buphone, Nerine, Ammocharis and Cybistetes. A new genus, Worsleya, has been proposed to separate the single species $W$. procera from the genus Amaryllis, with which it has no gene exchange, and from which it differs in several morphological characters. The genera Agapanthus and Tulbaghia are border-line genera between Amaryllidaceæ and Liliaceæ, now included in the former group. J. C. Th. Uphof reviews. the present position of the two genera, and describes the species included in each. As a background for taxonomic studies, W. S. Flory, jun., reports the chromosome numbers for verious species of Hemerocellideæ, Alstroemeriales and Amaryllidades which have been published since his earlier review in 1937.

Gardeners and students will be interested in a brief article by Kenyon L. Reynolds outlining the method for cross-pollinating Narcissi. This involves the ripening of pollen in a desiccator. V. T. Stoutemyer and Albert Close also discuss the latter question, suggesting the trial of freezing temperatures and definite humidities for storing pollen, and the use of mixed pollen, hormones, and other substances for overcoming certain types of sterility. Their paper is, however, a wider review of the whole question of reproduction. Many seeds of Amaryllids germinate without a rest period, while others have a more or. less protracted time of dormancy. Seeds of Hymenocallis occidentalis have an integument capable of photosynthesis, which appears to accelerate germination, though development can take place more slowly in the dark. It is interesting to note that vegetative propagation by seoring or cutting the base of the bulb is being employed more extensively in the Amaryllidaceæ. John V. Watkins adds a further note on the use of this method for Lycoris aurea.

L. S. Hannibal records the lesser bulb fly as a pest on several Amaryllids other than Narcissus. Lycoris squamigera and Homanthus multiflora appear to be even more heavily attacked than members of the genus Narcissus.

The natural order under discussion, however, seems to have but little acquaintance with pest or disease, and this factor should be added to that of superb garden beauty to inspire an even wider horticultural use of this interesting group.

\section{NEW WOODS FOR CROSS-ARMS FOR TELEGRAPH LINES}

A $\mathrm{N}$ article by G. Q. Lumsden (Bell Lab. Rec., 22, A No. 14; October 1944) discusses new woods for cross-arms and their preservation. Since the turn of the century, the open-wire lines of the Bell System (U.S.A.) have been carried mostly on Douglas fir and southern pine cross-arms. War emergency demands for these timbers have made it necessary, however, to seek substitutes, and the woods most readily available were red and jack pine from the Lake States and the inland type of Douglas fir from the north-west.

In testing out these alternatives it was decided to apply a preservative treatment to the new arms by an improved hot-and-cold bath process, instead of using the standard pressure processes regularly employed for southern pine arms. A solution of pentachlorphenol in petroleum was used instead of creosote for the cold bath. Pentachlorphenol is a comparatively new wood preservative, being practically soluble in water and leaving the surface of the wood clean.

About 1,100 cross-arms were treated at a time. These were laid in a tank and kept from floating by steel rails secured to the tank sides. Heavy lids were put on to hold heat, prevent excessive evaporation and keep out rain. The hot-and-cold bath nonpressure treatment was then applied. Creosote, heated to above $220^{\circ} \mathrm{F}$., was pumped in to fill the tank. From two to four hours later, depending on the condition of the timber treated and the outside temperature, this ereosote was pumped off. As soon as possible, and while the cross-arms were still hot, the tank was filled with a 5 per cent solution of pentachlorphenol in an aromatic petroleum at $90-125^{\circ} \mathrm{F}$. After allowing another two to four hours for this solution to be absorbed, the tank was again drained and the cross-arms removed for stacking.

At the end of the cold-bath treatment, the sapwood was completely penetrated and the heartwood was penetrated around the pinholes. Retention of preservative solution varied with the amount of sapwoo 